\title{
The Determination of Iron in Biological Material
}

\author{
By A. J. WOIWOD, The Wellcome Physiological Research Laboratories, Beckenham, Kent
}

\author{
(Received 28 June 1946)
}

In the course of investigations on protein hydrolysates used for preparing culture media, it was found that no satisfactory method for determining small quantities of iron $(0.5-10 \mu \mathrm{g} . / \mathrm{ml}$.) in such material existed. Wet ashing was reputed to give reliable results with biological material (Jackson, 1938; Thorp, 1941), but this method is time-consuming and the neutralization of the residual acid after digestion introduces adventitious iron, resulting in large and troublesome blanks. The alternative process of dry ashing in an electric muffle furnace offers a convenient and at first sight complete solution, but experience proves that this method introduces an unexpected chemical problem concerning iron in complex combination. It was found that recoveries of iron from such ashes were variable and low, and in addition, combination with $\alpha \alpha^{\prime}$-dipyridyl to develop a pigment suitable for colorimetric measurement was slow and incomplete.

The determination of small quantities of iron in dry ashes of material with a high $\mathrm{P}: \mathrm{Fe}$ ratio has been studied by many workers, and the diverse methods which have been suggested to overcome the difficulties, attributed to complex phosphate formation, reflect the present unsatisfactory situation (Elvehjem \& Hart, 1926; Elvehjem, 1930; Jackson, 1938; Howe, 1943, 1944; Bandemer \& Schaible, 1944; Stugart, 1931; Koenig \& Johnson, 1942). Methods which involved much manipulation after ashing, as, for instance, the complete removal of phosphates (Elvehjem \& Hart, 1926), were considered unsuitable, since the main reason for using dry ashing was the low level at which blanks could be kept. The simpler methods usually involved boiling with acid or alkali for varying times (Howe, 1944; Stugart, 1931). An iron complex resistant to this procedure, presumably similar to that reported in ashes of tomato and spinach (Jackson, 1938), was found to be present in ashes of protein hydrolysates. The present communication reports a procedure overcoming this interference and the development of a simple method of good precision for estimating iron.

\section{EXPERIMENTAL}

The method as finally developed consists in $(a)$ dry ashing the sample, $(b)$ precipitating the iron present as sulphide by means of ammonium sulphide solution and (c) dissolving the precipitated ferrous sulphide in acid in the presence of $\alpha \alpha^{\prime}$-dipyridyl. The resulting red colour is measured in an absorptiometer. The iron sulphide is not separated from the ash solution, and all reactions are carried out in the crucible in which the sample has been ashed. Blanks can therefore be kept low because of the very small amount of manipulation involved.

The method of ashing has been found to have a marked effect on the reproducibility of the method, and the one adopted is a modification of that used by Klumpp (1934) who damped his material with $\mathrm{H}_{2} \mathrm{SO}_{4}$ before ashing to prevent loss of iron. The $\mathrm{H}_{2} \mathrm{SO}_{4}$ acts as an effective ashing aid, and the white fluffy ashes so obtained dissolve readily and give no carbon residue of any kind.

When the search for a suitable method for determining iron was started, potassium thiocyanate was used as the chromogenic agent. This was found unsuitable owing to the necessity for strict $\mathrm{pH}$ control, and the poor stability of the colour formed limited the number of determinations able to be carried out at one time. $\alpha \alpha^{\prime}$-Dipyridyl was found to be a more suitable reagent, since the red-coloured complex it forms with ferrous ions is stable for a period of months (Thorp, 1941; Moss \& Mellon, 1942) and its colour is not affected over the $\mathrm{pH}$ range 2.5-8.5 (Moss \& Mellon, 1942).

It was observed that dry ashing of protein hydrolysates followed by $\mathrm{HCl}$ and sodium sulphite treatment for the reduction of iron gave non-reproducible results. Experimental study led to the conclusion that dry ashing resulted in a ferric complex stable to acid hydrolysis. A difficulty of the same kind was reported by Jackson (1938), who introduced the use of ammonium sulphide. This enabled ferrous sulphide to be recovered for subsequent treatment. While the application of this method in the original form, or modified by the use of adsorbents such as calcium phosphate, proved unsuccessful in our case, the use of ammonium sulphide for the purpose of bringing ferrous iron and $\alpha \alpha^{\prime}$-dipyridyl into quantitative reaction enabled the following experimental method to be successfully applied.

\section{METHOD \\ Apparatus}

Ashing can be carried out in platinum or silica dishes or in Royal Worcester porcelain crucibles, provided the latter are well cleaned with chromic acid before use. 


\section{Measurement of colour}

A Spekker absorptiometer with $1 \mathrm{~cm}$. cells and Wratten 61 green filters was used for all the colour measurements, but any other suitable instrument can be used.

\section{Reagents}

All reagents are A.R. and the distilled water is redistilled from glass.

Acids. $\mathrm{N}^{-} \mathrm{H}_{2} \mathrm{SO}_{4}$ and $\mathrm{N}$ and $0 \cdot 1 \mathrm{~N}-\mathrm{HCl}$. The hydrochloric acid solutions are prepared from glass-distilled constantboiling $(20 \%) \mathrm{HCl}$.

Ammonium sulphide solution. Freshly prepared for each set of determinations by bubbling $\mathrm{H}_{2} \mathrm{~S}$ through concentrated ammonia solution (sp.gr. $0 \cdot 880$ A.R.) for 2-5 min. The final solution should not be more than faintly yellow. A.R. ammonium sulphide is not suitable, as it tends to deposit sulphur under the experimental conditions. This deposit is most difficult to remove and makes estimation with the photoelectric absorptiometer impossible.

$\alpha \alpha^{\prime}$-Dipyridyl. A $1 \%(\mathrm{w} / \mathrm{v})$ solution in Fe-free 0.1 N-HCl This solution is rejected as soon as it shows more than a slight red colour.

Sodium sulphite. A $20 \%(\mathrm{w} / \mathrm{v})$ solution of $\mathrm{Na}_{2} \mathrm{SO}_{3} \cdot 7 \mathrm{H}_{2} \mathrm{O}$ prepared just before use.

pH 4.6 buffer. This is made by mixing $200 \mathrm{ml}$. of Msodium acetate with $100 \mathrm{ml}$. $\mathrm{N}-\mathrm{HCl}$ (iron-free) and making to 11 .

Standard Fe solution. This is made from pure iron wire or ferric ammonium sulphate. A primary standard containing $100 \mu \mathrm{g}$. $\mathrm{Fe} / \mathrm{ml}$. is conveniently prepared by dissolving $0.8636 \mathrm{~g}$. of $\mathrm{Fe}\left(\mathrm{NH}_{4}\right)\left(\mathrm{SO}_{4}\right)_{2} \cdot 12 \mathrm{H}_{2} \mathrm{O}$ in water, adding $100 \mathrm{ml}$. of $\mathrm{N} \cdot \mathrm{HCl}$ and making up to 11 .

\section{Standard curve}

For the method described a calibration curve was prepared for the Spekker absorptiometer over the range $0-100 \mu \mathrm{g} . \mathrm{Fe} / 10 \mathrm{ml}$. Colour development of standards was carried out by reducing with sodium sulphite and $\mathrm{HCl}$ in the presence of $\alpha \alpha^{\prime}$-dipyridyl (Thorp, 1941). The use of sodium sulphite and acid for reduction was considered preferable to ammonium sulphide as reduction was complete, the acid and sulphite buffered within the working $\mathrm{pH}$ range of $\alpha \alpha^{\prime}$ dipyridyl and the necessity for redissolving a ferrous sulphide precipitate was avoided. The standard iron solution was diluted so that it contained $20 \mu \mathrm{g}$. Fe/ml. Suitable quantities to cover the range $0-100 \mu \mathrm{g}$. Fe were pipetted into $10 \mathrm{ml}$. graduated centrifuge tubes and distilled water added to give a volume of $5 \mathrm{ml}$. Then $0.5 \mathrm{ml} .20 \%$ sodium sulphite solution, $0.5 \mathrm{ml} . \mathrm{N}-\mathrm{HCl}$ and $0.25 \mathrm{ml}$. $\alpha \alpha^{\prime}$-dipyridyl solution were added. The contents of each tube were well mixed and left for $15 \mathrm{~min}$., before making to $10 \mathrm{ml}$. and reading in the absorptiometer. Tubes showing any cloudiness were centrifuged before colour measurement, but in most cases this was not found necessary.

\section{Procedure}

Weigh or pipette a suitable quantity of material into a platinum, silica or Royal Worcester crucible. For hydrolysates containing between 0.5 and $10 \mu \mathrm{g}$. Fe/ml., 5-10 ml. has been found satisfactory. Add 2.5 ml. of $\mathrm{N}_{-}-\mathrm{H}_{2} \mathrm{SO}_{4} / 10 \mathrm{ml}$. (or $10 \mathrm{~g}$.) and evaporate on a water-bath to a consistency suitable for ashing. Protect samples on the water-bath from aerial contamination by shielding them with a sheet of glass. Ash at $500^{\circ}$. Cool the ash, add $1.0 \mathrm{ml}$. of $\mathrm{N}-\mathrm{HCl}$ and take to dryness on the water-bath. Cool, add $5 \mathrm{ml}$. of distilled water and $0.25 \mathrm{ml}$. of ammonium sulphide solution. Mix with swirling and again dry and cool. Add $2 \mathrm{ml}$. water, $0.5 \mathrm{ml}$. of $\alpha \alpha^{\prime}$-dipyridyl solution and $0.5 \mathrm{ml}$. $\mathrm{N}-\mathrm{HCl}$. Place the crucible on the water-bath just off the boil and leave $5 \mathrm{~min}$. with occasional swirling to assist complete solution of the ferrous sulphide. It is most important that complete solution is achieved, since this has been found to be the main cause of bad duplication of results. A black residue is sometimes seen if much copper is present and is centrifuged off at a later stage. Add $5 \mathrm{ml}$. of $\mathrm{pH} 4.6$ buffer to bring the reaction of the solution within the range for maximum colour development. Cool and transfer the contents of the crucible to a graduated centrifuge tube. Make up to $10 \mathrm{ml}$. and centrifuge to remove any suspended matter likely to interfere with colour matching. Read in the absorptiometer

\section{RESULTS}

Sixteen $10 \mathrm{ml}$. samples of a papain digest of horse muscle were analyzed and the following results obtained: $62 \cdot 0,63 \cdot 8,60 \cdot 7,61 \cdot 9,59 \cdot 2,61 \cdot 4,62 \cdot 1,62 \cdot 0$, $62 \cdot 1,63 \cdot 8,61 \cdot 5,59 \cdot 9,62 \cdot 8,61 \cdot 0,59 \cdot 7,60 \cdot 5 \mu \mathrm{g}$. $\mathrm{Fe} / 10 \mathrm{ml}$. hydrolysate. The mean was $61.5 \mu \mathrm{g}$. $\mathrm{Fe} / 10 \mathrm{ml}$., and the standard deviation from the mean $1.3 \mu \mathrm{g}$. $\mathrm{Fe} / 10 \mathrm{ml}$., giving a coefficient of variation of $2 \cdot 1 \%$.

\section{Table 1. Recoveries of iron from papain digest} of horse muscle and from milk

Fe found ( $\mu \mathrm{g} . / 5 \mathrm{ml}$.)

\begin{tabular}{|c|c|c|}
\hline Papain digest & $\begin{array}{c}\text { Papain digest } \\
+10 \mu \mathrm{g} . \mathrm{Fe}\end{array}$ & $\begin{array}{l}\text { Papain digest } \\
+20 \mu \mathrm{g} \text {. Fe }\end{array}$ \\
\hline $\begin{array}{l}31 \cdot 0 \\
31 \cdot 0 \\
30 \cdot 0 \\
\end{array}$ & $\begin{array}{l}40 \cdot 0 \\
41 \cdot 0 \\
41 \cdot 0 \\
\end{array}$ & $\begin{array}{l}50 \cdot 0 \\
52 \cdot 0 \\
49 \cdot 0 \\
\end{array}$ \\
\hline ge $\quad \overline{30.7}$ & $40 \cdot 7$ & $\overline{50 \cdot 3}$ \\
\hline covered (\%) & $100 \cdot 0$ & $98 \cdot 0$ \\
\hline
\end{tabular}

\begin{tabular}{|c|c|c|c|}
\hline & \multicolumn{3}{|c|}{ Fe found $(\mu \mathrm{g} . / 10 \mathrm{ml})}$. \\
\hline & Milk & Milk $+10 \mu \mathrm{g} . \mathrm{Fe}$ & Milk $+20 \mu \mathrm{g} \cdot{ }^{\prime} \mathrm{Fe}$ \\
\hline & $\begin{array}{l}4 \cdot 8 \\
4 \cdot 5 \\
4 \cdot 7\end{array}$ & $\begin{array}{l}15 \cdot 0 \\
15 \cdot 5 \\
14 \cdot 5\end{array}$ & $\begin{array}{l}25 \cdot 0 \\
25 \cdot 0 \\
25 \cdot 0\end{array}$ \\
\hline Average & $\overline{4 \cdot 7}$ & $15 \cdot 0$ & $\overline{25 \cdot 0}$ \\
\hline Fe recor & $d(\%)$ & $103 \cdot 0$ & $101 \cdot 5$ \\
\hline
\end{tabular}

In Table 1 are given the results of recovery experiments on $5 \mathrm{ml}$. samples of papain digest of horse muscle to which were added 10 and $20 \mu \mathrm{g}$. of $\mathrm{Fe}$ and a similar series with $10 \mathrm{ml}$. of fresh raw cows' milk. The iron was added as a solution of ferric ammonium sulphate before ashing, and ashings were in triplicate. 


\section{DISCUSSION}

The method described is based on two observations. The first, made by Jackson (1938), is that small amounts of iron can be quantitatively precipitated as sulphide from ashes of biological material with a high $\mathrm{P}: \mathrm{Fe}$ ratio. The second, that the ferrous sulphide so precipitated can be redissolved without separation from the interfering ions present, and combined quantitatively and preferentially with $\alpha \alpha^{\prime}$-dipyridyl, was made while trying to apply Jackson's methods to ashes of protein hydrolysates. These ashes contain an iron complex very resistant to acid hydrolysis. It is therefore unlikely to be iron pyrophosphate, which can be hydrolyzed by acids (Jackson, 1938; Howe, 1944). The nature of the complex is not known, but it may be significant that iron metaphosphates can be formed at $200-300^{\circ}$ and are stable up to $800^{\circ}$ (Brasseur, 1944). Direct experimental confirmation of the presence of the metaphosphate ion is difficult; its solutions, however, are known to have marked tendencies to sequester multivalent ions. After reduction and precipitation of iron as sulphide, one or more possible interfering ions are left in solution. It seemed that introduction of $\alpha \alpha^{\prime}$-dipyridyl and re-solution of the iron would be likely to lead to the preferential formation of stable ferrous dipyridyl rather than any of the unwanted ferric complexes. Any tendency for the iron to revert to the ferric state would be checked by the nascent $\mathrm{H}_{2} \mathrm{~S}$ evolved from the dissolving ferrous sulphide. This appeared to be the case.

\section{SUMMARY}

1. A method for determining iron in biological materials with a high $\mathrm{P}: \mathrm{Fe}$ ratio is described. It is applicable over the range $0 \cdot 5-10 \mu \mathrm{g}$. $\mathrm{Fe} / \mathrm{ml}$. All analytical manipulations, except the final centrifuging before colour reading, are performed in the crucible in which the sample has been ashed. Blanks are therefore kept at a minimum.

2. The method has proved satisfactory with protein hydrolysates and cows' milk and may be suitable for other materials where phosphate inter. ference is met.

\title{
REFERENCES
}

Bandemer, S. L. \& Schaible, P. J. (1944). Industr. Engng Chem. (Anal. ed.), 16, 317.

Brasseur, P. (1944). Bull. Soc. chim. Fr. 11, 2.

Elvehjem, C. A. (1930). J. biol. Chem. 86, 463.

Elvehjem, C. A. \& Hart, E. B. (1926). J. biol. Chem. 67, 43.

Howe, M. (1943). Cereal Chem. 20, 604.

Howe, M. (1944). Cereal Chem. 21, 412.
Jackson, S. H. (1938). Industr. Engng Chem. (Anal. ed.), 10, 302.

Klumpp, T. G. (1934). J. biol. Chem. 107, 213.

Koenig, R.A.\& Johnson, C.R.(1942). J.biol.Chem. 143, 159. Moss, M. L. \& Mellon, M. G. (1942). Industr. Engng Chem. (Anal. ed.), 14, 862.

Stugart, R. (1931). Industr. Engng Chem. (Anal. ed.), 3, 390. Thorp, R. H. (1941). Biochem. J. 35, 672.

\section{The Excretion of $l(-)$-Tyrosine in Urine}

\author{
By N. R. LAWRIE, Biochemical Laboratory, Addenbrooke's Hospital, Cambridge
}

(Received 23 August 1946)

Estimation of the $l(-)$-tyrosine content of urine is of value in the assessment of hepatic disease (Lichtman, 1934) and in the study of $l(-)$-tyrosine metabolism. The methods hitherto available lack the necessary sensitivity and specificity for the measurement of normal and pathological tyrosinuria. Thus the tyrosinase method of Lichtman \& Sobotka (1929) fails to detect the tyrosine present in normal urine, and Millon's reaction lacks specificity.

In the present communication a method is described which estimates only $l(-)$-tyrosine and $\boldsymbol{l - 3 : 4 - d i h y d r o x y p h e n y l a l a n i n e}$ and is sufficiently sensitive to measure the $l(-)$-tyrosine content of normal urine. The material estimated is referred to throughout this paper as $l(-)$-tyrosine because the presence of $l$-3:4-dihydroxyphenylalanine in normal urine is considered unlikely. The possibility that a mixture of the two substances has been estimated has not however been excluded. Data have been obtained for a small series of normal men and women and a rough assessment made of the $l(-)$ tyrosine output of a few normal domestic animals. The output of $l(-)$-tyrosine has also been measured in pregnancy and in a few pathological conditions.

Evidence for the occurrence of tyrosine in normal urine was obtained by Embden \& Reese (1906), although a pure product was not isolated. Pouchet (1880) is quoted by Neubauer \& Huppert (1910) as 